\title{
Cymbilabia sourioudongii (Orchidaceae), a new species from Lao PDR
}

\author{
Souvannakhoummane K..$^{{ }^{*}}$, Lanorsavanh S. ${ }^{1}$, Rakthai P. ${ }^{2}$, Kumar P. ${ }^{3}$ \& S.W. Gale ${ }^{3}$ \\ 'Department of Biology, Faculty of Science, National Univ. of Laos, Vientiane, Laos PDR \\ ${ }^{216}$ Tessaban 1 Road, Ra-Ngang, Sikhorabhumi, Surin - 32110, Thailand \\ ${ }^{3}$ Flora Conservation Department, Kadoorie Farm and Botanic Garden, Lam Kam Road, Lam Tsuen, Tai Po, \\ New Territories, Hong Kong S.A.R., P.R. China \\ *E-mail: keooudone1988@gmail.com
}

\begin{abstract}
Cymbilabia sourioudongii, a new species of epiphytic orchid is described and illustrated from Phou Khao Khouay National Protected Area of Laos PDR.
\end{abstract}

Keywords: Illegal orchid trade, New species, Phou Khao Khouay National Protected Area, Vandopsis.

\section{Introduction}

Cymbilabia D.K.Liu \& Ming H.Li was recently described as a monotypic genus of Orchidaceae from Asia based on C. undulata (Lindl.) D.K.Liu \& Ming H.Li (a" Vandopsis undulata (Lindl.) J.J.Sm., Vanda undulata Lindl.; Liu et al., 2020). This was done to maintain the genus Vandopsis Pfitzer monophyletic. Ormerod et al. (2021) included another species, C. shanica (Phillim. \& W.W.Sm.) Ormerod (Stauropsis shanica Phillim. \& W.M.Sm.), endemic to Myanmar. Morphological characteristics of Cymbilabia are similar to those of Vandopsis with respect to the monopodial habit, distichous leaves, resupinate flowers and 3-lobed lip. However, the genus is differentiated from the latter by its less branching stem, verrucose basal sheaths and subovate to triangular labellum side lobes (Liu et al., 2020).

An unidentified orchid known to be illegally traded across the border from Laos to Thailand over the past ten years recently appeared for sale online on several Thai websites (P. Rakthai pers. comm.). The epiphytic orchid caught the attention of the authors,

Received: 25.10.2020; Revised \& Accepted: 01.06.2021

Published Online: 16.10.2021 who traced the origin of the plants to the Phou Khao Khouay National Protected Area in central Laos. Phou Khao Khouay is an important area for orchid diversity in Laos, as exemplified by the recent discovery of several species new to science, including Paphiopedilum papilio-laoticum Schuit., Luang Aphay \& Iio (Schuiteman et al., 2018) and Coelogyne pseudoviscosa Elis.George, J.-C. George \& Rakthai (George et al., 2017). Specimens of the unidentified orchid were collected with permission from the National University of Laos. They were found to be morphologically similar to C. undulata but differed in several important aspects, and we, therefore, conclude that they represent a distinct, as yet undescribed species.

\section{Taxonomic Treatment}

Cymbilabia sourioudongii Souvann. \& Lanors., sp. nov.

Figs. 1 \& 2a-e

Similar to C. undulata but differs in having a more compact habit, narrowly elliptic-oblong to lanceolate leaves that are $2-3.7 \mathrm{~cm}$ long and $0.8-1.7 \mathrm{~cm}$ wide $(v s$. oblong, 9-15 cm long and $1.5-3 \mathrm{~cm}$ wide), smaller sepals and petals that are 7-18 $\mathrm{mm}$ long and 3-8 mm wide (vs. 24-40 $\mathrm{mm}$ long and 8-14 mm wide), a shorter labellum that is $5-9 \mathrm{~mm}$ long, which has semi-orbiculate side lobes (vs. 15-20 mm long with sub-ovate to triangular side lobes), a verrucose epichile ( $v s$. muricate with papillae).

Type: LAO PDR, Bolikhamxai province, Thaphabath district, Phou Khao Khouay National Protected Area, 1300 m a.s.1., 30.08.2020, S. Lanorsavanh \& K. Souvannakhoummane SL1982 


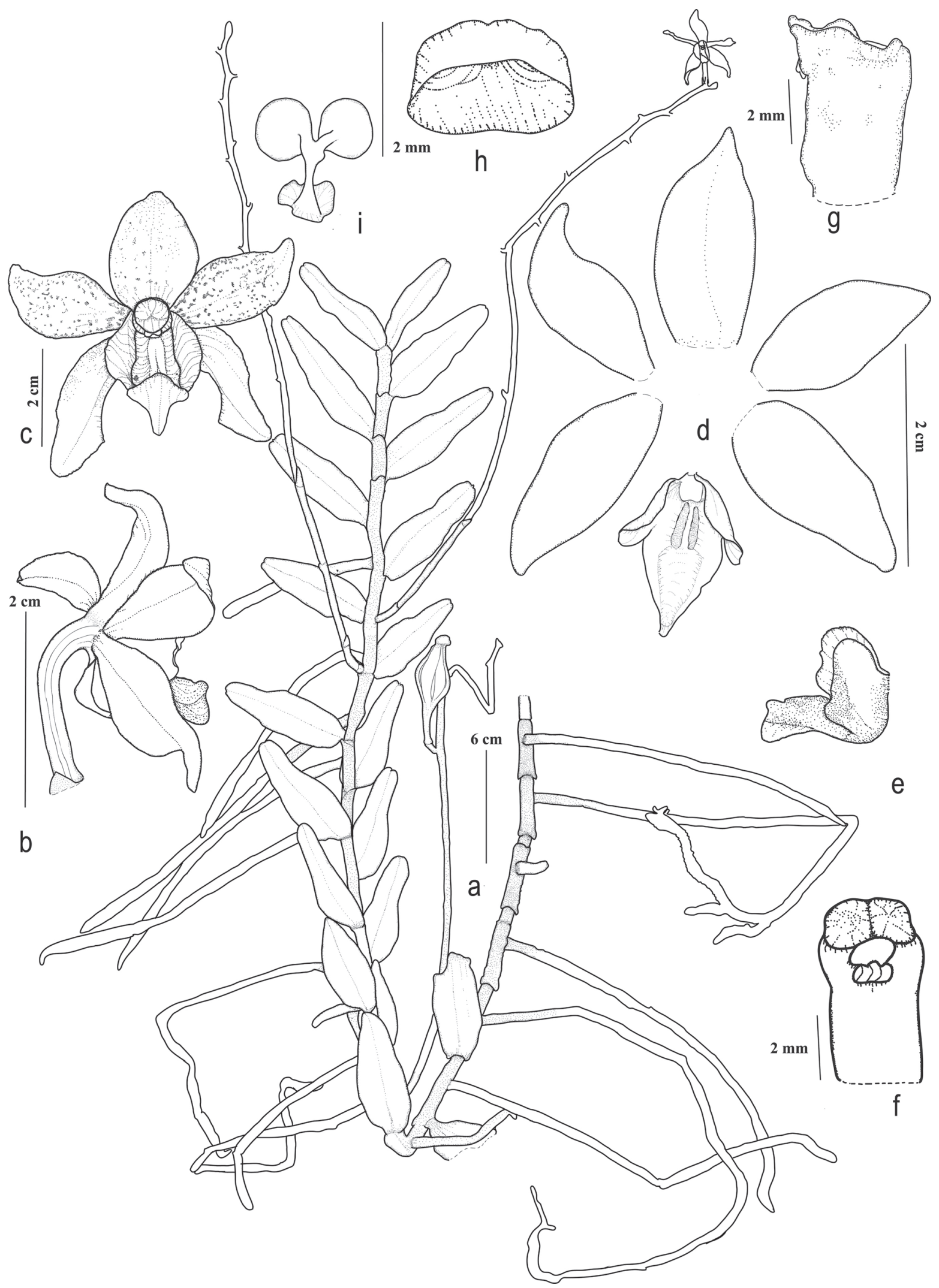

Fig. 1. Cymbilabia sourioudongii Souvann. \& Lanors.: a. Habit; b. Flower-lateral view; c. Flower-front view; d. Dissection of flower: labellum, petals and sepals; e. Labellum-lateral view; f. Column-front view; g. Column-lateral view; h. Anther cap; i. Pollinarium (from S. Lanorsavanh \& Souvannakhoummane SL1982; drawn by K. Souvannakhoummane). 

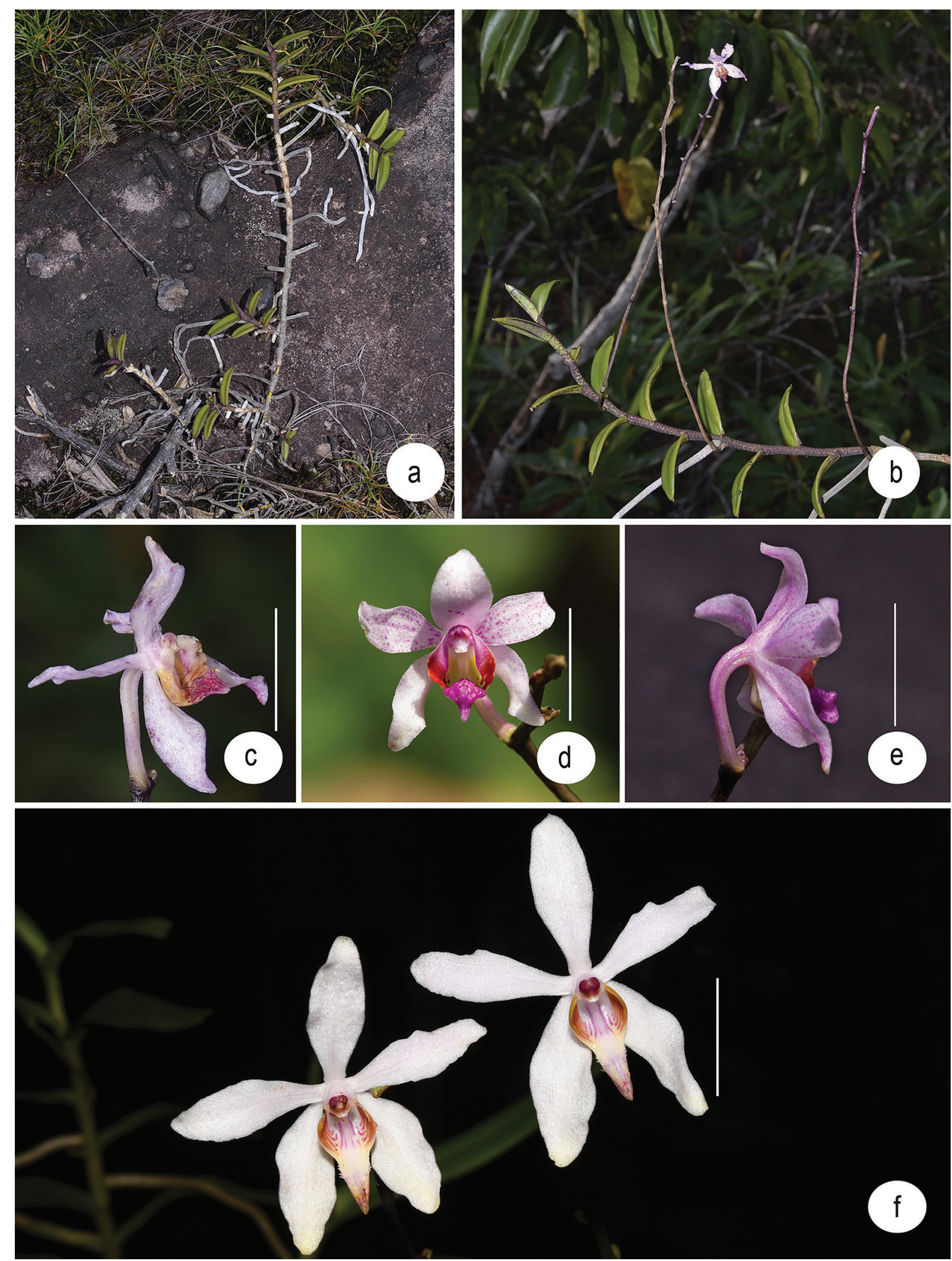

Fig. 2. Cymbilabia sourioudongii Souvann. \& Lanors (a-e) and congener (f): a. Plant in habitat; b. Flowering plant; c. Flower in habitat; d. Flower of plant growing in nursery; e. Flower-lateral view; f. Flowers of Cymbilabia undulata (Lindl.) D.K.Liu \& M. H.L. Scale bars 2 cm. (a-c from S. Lanorsavanh \& Souvannakhoummane SL1982; d-f from cultivated plants; photos a-c by S. Lanorsavanh; d-e by P. Rakthai; f by W. Buddhawong). 
(holo HNL [HNL0009858!]; iso FOF [FOF0005196!]).

Vernacular name: Ueang Sor Mouang (Purple flower orchid).

Moderately branched, lithophytic or epiphytic, monopodial orchid. Stems ascending to erect, robust, semi-woody, 30-120 cm long, 8-15 mm in diam., internodes 1-2 cm long, leafy only towards apex, lower portion leafless but with several thick, wiry, light grey to white flexuose stilt roots. Leaf sheath 1-3 cm long, dark brown with purple spots, pale green towards apex, verrucose. Leaves distichous, sessile, succulent, narrowly ellipticoblong to lanceolate, $2-3.7 \mathrm{~cm}$ long, $0.8-1.7 \mathrm{~cm}$ wide, apex sub-equally bi-lobed with distinct minute-mucro c. $1 \mathrm{~mm}$ long. Inflorescence lateral spike, arising from distal leaf axils, ascending to erect, stiff, 15-22 cm long, 1-4(-5)-flowered; peduncles terete, ascending to erect, $8-13 \mathrm{~cm}$ long, 1.5-2.2 $\mathrm{mm}$ in diam., reddish-brown flushed pinkish towards apex, bearing 1 or 2 small, triangular-ovate sterile bracts; rachis slightly zigzag, curved, 7-10 cm long. Floral bracts broadly triangular-ovate, 3-4 mm long, 2.5-3 mm wide, hyaline, acute, adpressed to pedicels. Flowers opening widely, $2.5-3 \mathrm{~cm}$ in diam.; pedicelled ovary terete, pale purple to white, curved, $8-1.2$ $\mathrm{mm}$ long, $1.7-2 \mathrm{~mm}$ in diam.; sepals and petals glossy, white flushed pink with purple-pink spots inside, almost white with purple spots outside; labellum purple, brown to yellow-orange; hypochile with two transverse purple or yellow stripes, side lobes yellow-orange with transverse purple-brown stripes, outer surface yellow with lightly pink and white; epichile dark purple with orange spots outside; column, anther cap yellow to white with purple spots. Dorsal sepal ovate to lanceolate, $12-18 \mathrm{~mm}$ long, $4.5-8 \mathrm{~mm}$ wide, margins entire, apex acute, hooked, glabrous. Lateral sepals narrowly ovate to lanceolate, 10-15 $\mathrm{mm}$ long, 4-5 mm wide, margins entire to slightly undulate, apex hooked, rounded, glabrous. Petals lanceolate to oblong, 7-15 mm long, 3-5 mm wide, apex obtuse, margins entire to slightly undulate, glabrous. Labellum without a spur, fleshy, geniculate, distinctly 3-lobed, divided into hypochile and epichile, 5-9 $\mathrm{mm}$ long from the base to apex; side lobes erect, embracing the column, semi-orbiculate, rounded at apex, 4-5 mm long, 2-2.5 mm wide; mid-lobe broadly triangularlanceolate, thickened, warty, 3.5-4 mm long, 2-3 $\mathrm{mm}$ wide at middle, margin entire, apex acute; disc bearing 2 keels, slightly verrucose to glabrous. Column simple, without wings or stelidia, stout, 2.5-3.5 mm long, 2-2.5 mm in diam.; anther cap cucullate, $2.2-2.4 \mathrm{~mm}$, shortly beaked. Pollinarium with very short stipe, c. $1.2 \mathrm{~mm}$ long; viscidium large, suborbicular, c. $0.8 \mathrm{~mm}$ long; pollinia 2 , unequal, each globular, $0.5 \mathrm{~mm}$ in diam., yellow, hard. Capsules not seen.

Flowering \& fruiting: Flowering from July to September, fruiting not seen.

Habitat: Growing on small trees and boulders in full sun in mixed semi-deciduous broad-leaved and coniferous forest at around $1100 \mathrm{~m}$ elevation.

Distribution: Cymbilabia sourioudongii is so far known only from the type locality in Phou Khao Khouay National Protected Area in Bolikhamxai province, central Laos.

Etymology: The name for this species honors His Excellency Dr. Sourioudong Sundara, Vice Minister of Education and Sport, Lao PDR, who is an experienced scientific researcher of Lao PDR.

Notes: Although Cymbilabia is morphologically similar to Papilionanthe Schltr., members of the former are distinguished from those of the latter by their narrowly elliptic-oblong to lanceolate leaves having a verrucose basal sheath, by their flowers lacking a spur, and by the tapering, fleshy, warty labellum mid-lobe. Although Liu et al. (2020) cited the boat-shaped lip as another diagnostic character of Cymbilabia, the labellum mid-lobe of C. sourioudongii is flat or raised, not concave.

At present, Cymbilabia sourioudongii is only known from Phou Khao Khouay National Protected Area in Bolikhamxai province, central Laos. More 
detailed botanical exploration of the area is required to better ascertain the species' occurrence and abundance before a conservation status assessment can be undertaken. This study underscores the ecological importance of the semi-evergreen and mixed deciduous zone of central Laos for the rich diversity of orchids it harbours, as concluded elsewhere (Kumar et al., 2016, 2018). It also highlights the need for redoubled effort to curtail the threat of illegal international wild orchid trade in the Indo-Burma region (Phelps \& Webb, 2015; Gale et al., 2019).

\section{Acknowledgements}

We are very grateful to Professor Bouakhaykhone Svengsuksa and Professor Vichith Lamxay (National University of Laos) and Dr. Sourioudong Sundara (Ministry of Education and Sport) for imparting extensive knowledge of the orchids of Laos during the preparation of this paper. We also thank Mr. Oda Yosuke for introducing us to our local guides.

\section{Literature Cited}

GALE S.W., KUMAR P., HINSLEY A., CHEUK M.L., GAO J., LIU H., LIU Z.L. \& S.J. WILLIAMS 2019. Quantifying the trade in wild-collected ornamental orchids in South China: diversity, volume and value gradients underscore the primacy of supply. Biological Conservation 238: 108-204. https://doi.org/10.1016/ j.biocon.2019.108204
GEORGE E., GeORGE J.C. \& P. RAKTHAI 2017. Coelogyne pseudoviscosa, a new Coelogyne species from Lao P.D.R. Orchideen Journal 5(2): 3-7.

KUMAR P., GALE S.W., SCHUITEMAN A., BOUAMANIVONG S. \& G.A. FISCHER 2016. Identifying orchid hotspots for biodiversity conservation in Laos: the limestone karst vegetation of Vang Vieng district, Vientiane province. Journal of Threatened Taxa 8: 9397-9417. https://doi.org/10.11609/jott.2826.8. 12.9397-9417

KUMAR P., GALE S.W., PEDERSEN H.Æ., PHAXAYSOMBATH T., BOUAMANIVONG S. \& G.A. FISCHER 2018. Additions to the orchid flora of Laos and taxonomic notes on orchids of the Indo-Burma region. Taiwania 63: 61-83. https://doi.org/10.6165/ tai.2020.65.47

LIU D.K., TU X.D., ZHAO Z., ZENG M.Y., ZHANG S., MA L., ZHANG G.Q., WANG M.M., LIU Z.J., LAN S.R., CHEN S.P. \& M.H. LI 2020. Plastid phylogenomic data yield new and robust insights into the phylogeny of Cleisostoma-Gastrochilus clades (Orchidaceae, Aeridinae). Molecular Phylogenetics and Evolution 145: e106729. https://doi.org/10.1016/ j.ympev.2019.106729

ORMEROD P., KURZWEIL H. \& S. WATTHANA 2021. Annotated List of Orchidaceae for Myanmar. Phytotaxa 481: 87. https://doi.org/10.11646/phytotaxa. 481.1.1

PHELPS J. \& E.L. WEBB 2015. "Invisible" wildlife trades: Southeast Asia's undocumented illegal trade in wild ornamental plants. Biological Conservation 186: 296-305. https://doi.org/10.1016/j.biocon.2015.03.030

SCHUITEMAN A., LUANG A.S. \& S. ILO 2018. Paphiopedilum papilio-laoticus (Orchidaceae), a new species from Laos. Orchideen Journal 6(4): 3-5. 